\title{
Hubungan Pola Asuh Orang Tua dengan Perkembangan Motorik Halus Anak Balita di Puskesmas Tampaksiring II
}

\author{
Anace Iwo ${ }^{1}$, Ni Made Ari Sukmandari ${ }^{2}$, Claudia Wuri Prihandini \\ 1,2,3 Prodi Keperawatan STIKES Surya Global Yogyakarta, Indonesia
}

\begin{abstract}
Abstrak
Perkembangan anak dibawah lima tahun (balita) merupakan bagian yang sangat penting karena berkaitan antara proses biologis, proses sosial-emosional dan proses kognitif. Salah satu faktor dalam perkembangan anak yaitu lingkungan pengasuhan. Dalam pengasuhan, peran orang tua sangat penting untuk memantau agar anak dapat tumbuh dan berkembang dengan baik. Tujuan penelitian ini adalah mengidentifikai hubungan pola asuh orang tua dengan perkembangan motorik halus anak balita di wilayah kerja Puskesmas Tampaksiring II Kabupaten Gianyar. Penelitian ini menggunakan metode deskritif korelasional dengan pendekatan cross sectional. Sampel penelitian ini sebanyak 314 orang dengan teknik pengambilan sampel menggunakan consecutive sampling. Data dianalisis menggunakan uji korelasi rank spearman. Hasil penelitian menunjukkan bahwa sebagian besar pola asuh orang tua tergolong baik yaitu sebanyak 160 responden $(51,0 \%)$. Sebagian besar balita yang menjadi responden telah lulus pada tahap perkembangan motorik halusnya, yaitu sebanyak 291 orang $(92,7 \%)$. Hasil uji Spearman Rank, didapatkan hasil nilai $\rho=0,000$, yang menunjukkan ada hubungan signifikan antara pola asuh orang tua dengan perkembangan motorik halus pada anak balita.
\end{abstract}

Kata Kunci: Pola asuh; motorik halus; balita; tumbuh kembang

\begin{abstract}
The development of children under five years (toddlers) is a very important part because it is related to biological processes, social-emotional processes, and cognitive processes. One of the factors in children's development is the nurturing environment. In parenting, the role of parents is very important to monitor so that children can grow and develop properly. The purpose of this study was to determine the correlation between parenting style and fine motoric development of children under five in the working area of the Puskesmas Tampaksiring II, Gianyar Regency. This study used a correlational descriptive method with a cross-sectional approach. The sample of this study was 314 people with the sampling technique using consecutive sampling. Data were analyzed using the Spearman rank correlation test. The results showed that most of the parenting styles were good as many as 160 respondents (51.0\%) and most of the fine motor development in graduating toddlers were 291 respondents (92.7\%). The result of the Spearman Rank test showed that the value of $\rho=0.000$, so the interpretation was that there was a correlation between parenting style and fine motoric development of children under five in the working area of Puskesmas Tampaksiring II Gianyar Regency. The conclusion in this study is that there is a correlation between parenting style and fine motoric development of children under five in the working area of Puskesmas Tampaksiring II Gianyar Regency.
\end{abstract}

Keywords: parenting; fine motor; toddler; growth and development 


\section{PENDAHULUAN}

Perkembangan anak dibawah lima tahun (balita) merupakan bagian yang sangat penting (Kemenkes RI, 2013). Pada masa ini anak juga mengalami periode kritis. Berbagai bentuk penyakit, kekurangan gizi, serta kekurangan kasih sayang maupun kekurangan stimulasi pada usia ini akan membawa dampak negatif yang menetap sampai dewasa berkaitan dengan masa dewasa bahkan sampai usia lanjut (Depkes RI, 2013). Perkembangan anak juga tidak terlepas dari peran caregiver atau orang yang merawat balita (Lely \& Soetjiningsih, 2010). Caregiver paling banyak diperankan oleh orang tua atau orang terdekat anak. Mereka seharusnya mengenali dan memahami tentang kebutuhan anak serta berkomunikasi dan berinteraksi dengan anak (WHO, 2012).

Proses utama perkembangan anak merupakan hal yang saling berkaitan antara proses biologis, proses sosial-emosional dan proses kognitif. 3 (ketiga) hal tersebut akan saling berpengaruh satu sama lain dan sepanjang perjalanan hidup manusia. Selama proses perkembangan tidak tertutup kemungkinan anak menghadapi berbagai masalah yang akan menghambat proses perkembangan selanjutnya. Perkembangan tersebut mencakup perkembangan perilaku sosial,bahasa, kognitif, fisik atau motorik (motorik kasar dan motorik halus) (Cahyono, 2014). Salah satu faktor dalam perkembangan anak yaitu lingkungan pengasuhan. Dalam pengasuhan peran orang tua sangat penting untuk memantau agar anak dapat tumbuh dan berkembang dengan baik. Orang tua perlu mengetahui dan mengenali ciri-ciri serta prinsip perkembangan seorang anak. Interaksi antara anak dan orang tua sangat bermanfaat bagi proses perkembangan anak secara keseluruhan. Anak yang pertumbuhan dan perkembanganya baik akan menjamin kelangsungan hidup yang baik untuk masa depannya kelak (Adistie et al., 2018).

Pola asuh orang tua bertujuan agar anak dapat tumbuh dan berkembang dengan optimal. Dalam penerapan pola asuh, orang tua perlu memperhatikan keunikan anak. Anak memiliki kekhasan sifatsifat yang berbeda dari satu anak dengan anak yang lain, sehingga orang tua dapat menerapkan beberapa pola asuh secara bergantian untuk menghadapi anak. Pengasuhan keluarga selama 5 tahun pertama kehidupan sangat berpengaruh terhadap 4 dominan perkembangan yaitu motorik, kognitif, bahasa dan sosial-emosional anak. berbagai aspek inilah sangat berpengaruh terhadap perkembangan dan perilaku anak dimasa mendatang (Situmorang et al., 2016). Pada saat ini berbagai metode deteksi dini untuk mengetahui gangguan perkembangan anak telah dibuat. Demikian pula dengan skrining untuk mengetahui penyakit-penyakit yang potensial yang dapat mengakibatkan gangguan perkembangan anak. skrining perkembangan merupakan prosedur rutin dalam pemeriksaan tumbuh kembang anak sehari-hari yang dapat memberikan petunjuk ada tidaknya sesuatu yang perlu mendapat perhatian (Dhamayanti, 2006).

Seorang anak dapat mengalami keterlambatan perkembangan dihanya satu ranah perkembangan saja atau dapat pula di lebih dari satu ranah perkembangan. Keterlambatan perkembangan umum atau 
global developmental delay merupakan keadaan keterlambatan perkembangan yang bermakna ada dua atau lebih ranah perkembangan. Sekitar 5 (lima) hingga 10\% anak diperkirakan mengalami keterlambatan perkembangan. Data angka kejadian keterlambatan perkembangan umum belum diketahui dengan pasti, namun diperkirakan sekitar 1 (satu) hingga 3\% anak dibawah usia 5 (lima) tahun mengalami keterlambatan perkembangan umum (Hartanto et al., 2011). Departemen Kesehatan RI dalam (Widati, 2013) melaporkan bahwa 0,4 juta (16\%) balita Indonesia mengalami gangguan perkembangan, baik perkembangan motorik halus dan kasar, gangguan pendengaran, kecerdasan kurang dan keterlambatan bicara. Sedangkan menurut dinas kesehatan dalam (Widati, 2013) sebesar $85.779(62,02 \%)$ anak usia prasekolah mengalami gangguan perkembangan. Cakupan pelayanan kesehatan anak balita di provinsi bali tahun 2018 sebesar 97\%, dimana angka ini masih dibawah target yang diharapkan yaitu 98,4\%. Bila dilihat berdasarkan kabupaten kota, maka hanya ada 5 (lima) kabupaten kota yaitu Denpasar, Kab Badung, Kab Tabanan, Kab Gianyar, Kab Bangli, dan Kab Buleleng yang telah mencapai target yang diharapkan (Dinkes Provinsi Bali, 2018).

Cakupan balita di Puskesmas Tampaksiring II pada tahun 2019 yaitu bulan Januari sebanyak $1690(8,97 \%)$ anak balita, februari sebanyak 1652 (8,88\%) anak balita, Maret sebanyak $1641(8,82 \%)$ anak balita, april sebanyak 1630 (8,76 \%) anak balita, Mei sebanyak 1629 (8,75\%) anak balita, juni sebanyak $1608(8,64 \%)$ anak balita, Juli sebanyak $1579(8,48 \%)$ anak balita, Agustus sebanyak 1660 $(8,92 \%)$ anak balita, September sebanyak $1714(9,21 \%)$ anak balita, Oktober sebanyak $1770(9,51 \%)$ anak balita, November sebanyak 1785 (9,59\%) anak balita, dan Desember sebanyak 256 (1,42\%) anak balita (Puskesmas Tampaksiring II, 2019) berdasarkan survey pendahuluan dengan cara pengamatan sementara yang dilakukan peneliti terhadap $10 \mathrm{ibu}$ yang membawa anaknya untuk di timbang berat badan ke Puskesmas Tampaksiring II Kabupaten Gianyar pada tanggal 25 Mei 2020 hasil yang didapatkan 2 ibu yang selalu memberikan penjelasan mengenai hal-hal yang tidak dimengerti oleh anak, memandikan, menemanim anaknya bermain, terlihat anaknya mandiri, mudah berinteraksi dengan orang lain, ceria, penurut, aktif dalam beraktivitas dan mengalami perkembangan yang pesat. Sedangkan 3 ibu yang jarang dalam memberikan penjelasan, membebaskan anaknya dalam melakukan hal apapun tanpa ada batasan, terlihat anaknya manja, kurang mandiri, dan kurang matang dalam perkembangannya. dan 5 ibu yang tidak pernah memberikan penjelasan kepada anaknya, membentak ketika anaknya menangis, menghukum anaknya ketika melakukan kesalahan dan tidak mematuhi perintah orang tua, terlihat anaknya pendiam, penakut, sulit bergaul dan berkumpul dengan teman sebayanya, dan sering bertengkar. Berdasarkan data-data dan studi pendahuluan yang diperoleh, maka penelitian ini dilakukan untuk mengkaji hubungan pola asuh orang tua dengan perkembangan motorik halus anak balita di wilayah kerja Puskesmas Tampaksiring II Kabupaten Gianyar Bali”. 


\section{METODE}

Penelitian ini adalah penelitian kuantitatif rancangan cross sectional. Populasi penelitian adalah balita di wilayah kerja Puskesmas Tampaksiring II Kabupaten Gianyar Bali. Sampel penelitian adalah 341 balita yang dipilih menggunakan teknik consecutive sampling. Variabel penelitian adalah pola asuh orang tua dan perkembangan motorik halus anak balita. Pengumpulan data menggunakan kuesioner. Data dianalisis menggunakan uji Spearman Rank.

\section{HASIL PENELITIAN}

\section{Karakteristik Responden Berdasarkan Umur}

Tabel 1. Distribusi Frekuensi Responden Berdasarkan Umur

\begin{tabular}{ccc}
\hline Umur & $\mathrm{n}$ & $\%$ \\
\hline $25-36$ bulan & 115 & 36,6 \\
$36-48$ bulan & 126 & 40,1 \\
$49-60$ bulan & 73 & 32,2 \\
\hline Total & 314 & 100,0 \\
\hline
\end{tabular}

Berdasarkan tabel 1, dari 314 responden didapatkan bahwa umur responden terbanyak berada pada rentan 36-48 bulan sebanyak 126 responden $(40,1 \%)$ dan paling sedikit berada pada rentan umur 4960 bulan sebanyak 73 responden $(32,2 \%)$.

\section{Karakteristik Responden Berdasarkan Jenis Kelamin}

Tabel 2. Distribusi Frekuensi Responden Berdasarkan Jenis Kelamin

\begin{tabular}{ccc}
\hline Jenis kelamin & $\mathrm{n}$ & $\%$ \\
\hline Laki-laki & 130 & 41,4 \\
Perempuan & 184 & 58,6 \\
\hline Total & 314 & 100,0 \\
\hline
\end{tabular}

Tabel 2 menunjukkan bahwa dari 314 responden didapatkan bahwa jenis kelamin responden terbanyak yaitu perempuan sebanyak 184 responden $(58,6 \%)$ dan laki-laki sebanyak 130 responden $(41,4 \%)$.

\section{Karakteristik Responden Berdasarkan Status Gizi}

Tabel 3. Distribusi Frekuensi Responden Berdasarkan Status Gizi

\begin{tabular}{ccc}
\hline Status Gizi & $\mathrm{n}$ & $\%$ \\
\hline Buruk & 0 & 0,0 \\
Kurang & 25 & 8,0 \\
Baik & 247 & 78,7 \\
Lebih & 42 & 13,4 \\
\hline Total & 314 & 100,0 \\
\hline
\end{tabular}

Berdasarkan tabel 3 dari 314 responden didapatkan bahwa status gizi responden terbanyak yaitu gizi baik sebanyak 247 responden $(78,7 \%)$ dan paling sedikit yaitu gizi kurang sebanyak 25 responden $(8,0 \%)$. 


\section{Pola Asuh Orang Tua}

Tabel 4. Kategori Pola Asuh Orang Tua terhadap Balita

\begin{tabular}{ccc}
\hline Pola asuh orang tua & $\mathrm{n}$ & $\%$ \\
\hline Sangat baik & 154 & 49,0 \\
Baik & 160 & 51,0 \\
Kurang & 0 & 0,0 \\
\hline Total & 314 & 100,0 \\
\hline
\end{tabular}

Tabel 4 menunjukkan bahwa dari 314 responden didapatkan bahwa sebagian besar pola asuh orang tua tergolong baik sebanyak 160 responden $(51,0 \%)$.

\section{Perkembangan Motorik Halus}

Tabel 5. Perkembangan Motorik Halus Responden

\begin{tabular}{ccc}
\hline Perkembangan motorik halus & $\mathrm{n}$ & $\%$ \\
\hline Lulus & 291 & 92,7 \\
Gagal & 23 & 7,3 \\
\hline Total & 314 & 100,0 \\
\hline
\end{tabular}

Tabel 5 menunjukkan bahwa dari 314 responden didapatkan bahwa sebagian besar perkembangan motorik halus pada balita lulus sebanyak 291 responden $(92,7 \%)$.

\section{Hubungan Pola Asuh Orang Tua Dengan Perkembangan Motorik Halus Anak Balita}

Tabel 6. Hubungan Pola Asuh Orang Tua dengan Perkembangan Motorik Halus Anak Balita

\begin{tabular}{|c|c|c|c|c|c|c|c|c|}
\hline \multirow{3}{*}{ Pola asuh } & \multicolumn{6}{|c|}{ Perkembangan motorik halus } & \multirow{2}{*}{\multicolumn{2}{|c|}{ Total }} \\
\hline & \multicolumn{2}{|c|}{ Lulus } & \multicolumn{2}{|c|}{ Gagal } & \multicolumn{2}{|c|}{ Menolak } & & \\
\hline & $\mathrm{n}$ & $\%$ & $\mathrm{n}$ & $\%$ & $\mathrm{n}$ & $\%$ & $\mathrm{n}$ & $\%$ \\
\hline Sangat baik & 151 & 98,1 & 3 & 1,9 & 0 & 0,0 & 154 & 100,0 \\
\hline Baik & 140 & 87,5 & 20 & 12,5 & 0 & 0,0 & 160 & 100,0 \\
\hline Kurang & 0 & 0,0 & 0 & 0,0 & 0 & 0,0 & 0 & 0,0 \\
\hline \multirow[t]{2}{*}{ Total } & 291 & 92,7 & 23 & 7,3 & 0 & 0,0 & 314 & 100,0 \\
\hline & & \multicolumn{2}{|c|}{$\mathrm{r}=0,202$} & $\rho=0, c$ & & & & \\
\hline
\end{tabular}

Hasil uji analisis menggunakan uji Spearman Rank, didapatkan hasil nilai $\rho=0,000$ sehingga nilai $\rho$ value $\leq 0,05$. Hasil ini menunjukkan ada hubungan pola asuh orang tua dengan perkembangan motorik halus anak balita di wilayah kerja Puskesmas Tampaksiring II Kabupaten Gianyar. Pada koefisien (r) telah didapatkan 0,202 yang artinya bahwa hubungan pola asuh orang tua dengan perkembangan motorik halus anak balita memiliki korelasi yang lemah.

\section{PEMBAHASAN}

\section{Pola asuh orang tua}

Berdasarkan hasil penelitian didapatkan bahwa sebagian besar pola asuh orang tua tergolong baik sebanyak 160 responden $(51,0 \%)$. Hal ini disebabkan karena orang mengasuh anak supaya menjadi dirinya sendiri, membimbing anak kepada hal-hal yang bermanfaat, melibatkan anak untuk 
mencari jalan keluar terbaik, memberikan kesempatan kepada anak untuk mengungkapkan perasaannya dan selalu membuat keputusan dengan mempertimbangkan dari pendapat anak.

Temuan ini sejalan dengan penelitian yang dilakukan oleh Fatimah (2012), didapatkan bahwa sebagian besar responden memiliki pola asuh baik sebanyak 56,8\%. Pola asuh orang tua yang baik dengan selalu mengepresikan kasih sayang (memeluk, mencium, memberi pujian), melatih emosi dan melakukan pengontrolan pada anak akan berakibat anak merasa diperhatikan dan akan lebih percaya diri, sehingga hal ini akan membentuk pribadi anak yang baik. Hal ini akan sangat berpengaruh terhadap perkembangan anak sejak dini yang meliputi perkembangan personal sosial, bahasa, motorik halus dan motorik kasar. Anak yang merasa diperhatikan dan disayangi oleh orang tuanya tidak ada rasa takut untuk bergaul dengan orang lain, anak lebih berekspresif, kreatif, tidak takut untuk mencoba hal-hal baru sehingga perkembangan anak terutama anak-anak di bawah 5 tahun akan maksimal.

Penelitian lainnya juga mendukung temuan penelitian ini yaitu penelitian dari Doni \& Mukhtar (2020), menunjukan bahwa lebih dari separuh $(51,7 \%)$ responden memiliki pola asuh orangtua yang baik. Dengan adanya pola asuh orang tua yang baik tentang tumbuh kembang, sangat membantu anak mencapai dan melewati pertumbuhan dan perkembangan sesuai tingkatan usianya dengan normal. Dengan lebih mengetahui tentang tumbuh kembang anak diharapkan pertumbuhan dan perkembangan anaknya lebih maksimal sehingga kedepannya akan menghasilkan penerus generasi yang lebih baik.

Pola asuh dapat diartikan sebagai sistem, cara kerja atau bentuk dalam upaya menjaga, merawat, mendidik dan membimbing anak kecil supaya dapat berdiri sendiri. Selain itu, pola asuh orang tua dapat diartikan sebagai interaksi antara anak dan orang tua selama mengadakan kegiatan pengasuhan. Pola pengasuhan adalah proses memanusiakan atau mendewasakan manusia secara manusiawi, yang harus disesuaikan dengan situasi dan kondisi serta perkembangan zaman (Hasanah, 2016). Menurut asumsi peneliti, pola asuh yang baik dalam sangat penting diterapkan dalam keluarga yang memiliki anak balita. Pola asuh orang tua akan membentuk karakter anak, karena itu hendaknya orang tua memberikan stimulasi yang cukup bagi anak karena jika itu kurang akan mengakibatkan kemampuan sosialisi, bahasa, motorik halus dan kasar menjadi terlambat. Lingkungan keluarga yang menunjang akan mendukung tumbuh kembang pada anak usia dini, karena proses pertumbuhan dan perkembangan seorang anak sangat pesat dan dapat berpengaruh bagi kehidupan selanjutnya.

\section{Perkembangan motorik halus anak balita}

Berdasarkan hasil penelitian didapatkan bahwa sebagian besar perkembangan motorik halus pada balita lulus sebanyak 291 responden $(92,7 \%)$. Hal ini disebabkan karena anak dapat melakukan tugas pada sektor motorik halus-adaptif yang terletak disebelah kanan garis umur.

Temuan ini sejalan dengan penelitian yang dilakukan oleh Fatimah (2012), didapatkan bahwa sebagian besar perkembangan anak dalam batas normal 72,7\%. Perkembangan anak sangat dipengaruhi oleh agen sosialnya. Hal yang paling utama dalam proses perkembangan sosial adalah keluarga yaitu orang tua dan saudara kandung. Anak sebagai bagian dari anggota keluarga, dalam 
petumbuhan dan perkembangannya tidak akan terlepas dari lingkungan yang merawat dan mengasuhnya. Penelitian lainnya juga mendukung temuan penelitian ini yaitu penelitian dari Doni \& Mukhtar (2020), menunjukan bahwa lebih dari separuh (51,6\%) responden dengan perkembangan yang sesuai. Perkembangan anak yang sesuai didukung oleh faktor lingkungan yang baik diantaranya pemberian stimulasi ibu yang adekuat dan sesuai dengan tahap perkembangan anak.

Perkembangan adalah suatu proses yang terjadi secara simultan dengan pertumbuhan yang menghasilkan kualitas individu untuk berfungsi, yang dihasikan melalui proses pematangan dan proses belajar dari lingkungannya (Supartini, 2014). Perkembangan motorik halus adalah perkembangan gerakan yang menggunakan otot-otot halus atau sebagian anggota tubuh tertentu, yang dipengaruhi oleh kesempatan untuk belajar dan berlatih. Misalnya, kemampuan memindahkan benda dari tangan, mencoret-coret, menyusun balok, menggunting, menulis, dan sebagainnya (Aisyah, 2011).

Menurut asumsi peneliti, perkembangan motorik halus yang baik sangat penting bagi balita, karena dapat berpengaruh bagi kehidupan selanjutnya. Sehingga perlu adanya stimulasi motorik halus oleh orang tua agar dapat merangsang kemampuan dasar anak secara optimal. Stimulasi juga dapat berupa kehangatan dan cinta tulus yang diberikan orang tua. Disini stimulasi juga dapat berfungsi sebagai penguat yang bermanfaat bagi perkembangan anak, termasuk perhatian dan kasih sayang dari orang tua. Peran orang tua mempengaruhi perkembngan motorik anak berkembang dengan baik.

\section{Hubungan pola asuh orang tua dengan perkembangan motorik halus anak balita}

Berdasarkan hasil penelitian yang telah dilakukan di wilayah kerja Puskesmas Tampaksiring II Kabupaten Gianyar didapatkan nilai $\rho=0,000$, maka ada hubungan pola asuh orang tua dengan perkembangan motorik halus anak balita di wilayah kerja Puskesmas Tampaksiring II Kabupaten Gianyar. Hasil penelitian ini sejalan dengan penelitian yang telah dilakukan oleh Munir et al., (2019), mengemukakan bahwa ada hubungan antara pola asuh dalam menstimulasi perkembangan motorik halus anak. Pola asuh orang tua yang baik akan membantu perkembangan motorik halus yang dicapai bahkan lebih/advanced karena anak diberi kesempatan untuk berlatih dan belajar untuk terampil dan lebih kreatif sesuai dengan kemampuan anak.

Penelitian Diana (2019), menunjukkan bahwa ada hubungan pola asuh orangtua dengan perkembangan motorik halus anak usia prasekolah di PAUD Harapan Bunda Surabaya. Perkembangan motorik sangat dipengaruhi oleh peran orangtua dalam mendidik dan mengasuh anaknya. Pola asuh demokratis dapat memberikan stimulus yang dapat diterima anak dengan baik. Stimulus yang diberikan melalui pola asuh yang baik dapat mengembangkan motorik halus anak dengan lebih baik. Setiap anak adalah individu yang unik karena faktor bawaan dan pola asuh orangtua yang berbeda, maka pencapaian kemampuan anak juga berbeda. Maka sangat penting untuk memilih jenis pola asuh yang tepat agar perkembangan motorik halus anak prasekolah menjadi normal sesuai tahap perkembangan. 
Menurut pandangan para ahli psikologi dan sosiologi berkata lain. Pola asuh dalam pandangan Singgih D Gunarsa (1991) sebagai gambaran nyang dipakai orang tua untuk mengasuh (merawat, menjaga, mendidik) anak. Sedangkan Chabib Thoha (1996), pola asuh adalah suatu cara terbaik yang dapat ditempuh orang tua dalam mendidik anak sebagai perwujudan dan rasa tanggung jawab kepada anak (Tridhonanto, 2014). Peran orang tua pada dasarnya mengarahkan anak-anak sebagai generasi unggul, karena potensi anak tidak akan tumbuh dengan sendirinya tanpa bantuan orang tua. Adapun solusi atau pola asuh yang terbaik dalam perkembangan anak adalah tipe pola asuh demokratis. Hal ini, disebabkan bahwa dalam pola asuh tipe ini bercirikan orang tua yang cenderung menganggap sederajat hak dan kewajiban anak dibanding dirinya karena pada prakteknya tipe pola asuh demokratis ini, para orang tua memberi kebebasan dan bimbingan kepada anak. Orang tua banyak memberi masukan-masukan dan arahan terhadap apa yang dilakukan oleh anak. Orang tua bersifat obyektif, perhatian dan kontrol terhadap perilaku anak (Hasanah, 2016).

Menurut asumsi peneliti, ada hubungan pola asuh orang tua dengan perkembangan motorik halus anak balita. Jadi dapat disimpulkan bahwa semakin baik pola asuh orang tua maka semakin baik pula perkembangan motorik halus anak balita. Perkembangan anak bukan hanya dipengaruhi oleh pola asuh orang tua secara umum tetapi orang tua harus memperhatikan dan memahami gaya yang digunakan ketika berinteraksi dengan anak serta bagaimana cara orang tua untuk mendisiplinkan anak yang selanjutnya disebut dengan pola asuh orang tua. Orang tua tidak boleh menghukum atau menjauhkan diri dari anak, sebaliknya orang tua harus mengembangkan aturan-aturan dan memberikan kasih sayang kepada anak agar anak dapat mencapai tugas perkembangan sesuai usia anak.

\section{KESIMPULAN}

Ada hubungan pola asuh orang tua dengan perkembangan motorik halus anak balita di wilayah kerja puskesmas Tampaksiring II Kabupaten Gianyar dengan nilai $\mathrm{p}=0,000$, dimana terdapat hubungan positif dengan nilai $r=0,202$ yang artinya semakin baik pola asuh orang tua maka semakin baik perkembangan motorik halus anak.

Diharapkan petugas kesehatan, tenaga kesehatan lebih meningkatkan lagi deteksi dini terhadap penyimpangan perkembangan dan dapat menerapkan pemeriksaan DDST Denver II/KPSP untuk anak balita secara rutin, serta memberikan penyuluhan pada ibu tentang cara menstimulasi perkembangan anak, untuk dapat diterapkan dalam kehidupan sehari-hari

\section{DAFTAR PUSTAKA}

Adistie, F., Lumbantobing, V. B. M., \& Maryam, N. N. A. (2018). Pemberdayaan kader kesehatan dalam deteksi dini stunting dan stimulasi tumbuh kembang pada balita. Media Karya Kesehatan, 1(2), 173-184. https://doi.org/10.24198/mkk.v1i2.18863 
Cahyono, A. D. (2014). Pengaruh stimulasi orang tua terhadap perkembangan sosial anak usia toddler. Jurnal AKP, 9(1), $1-9$. http://ejournal.akperpamenang.ac.id/index.php/akp/article/download/83/67

Depkes RI. (2013). Peraturan menteri kesehatan republik indonesia nomor 71 tahun 2013 tentang pelayanan kesehatan pada jaminan kesehatan nasional. Kementerian Kesehatan RI.

Dhamayanti, M. (2006). Kuesioner praskrining perkembangan (KPSP) anak. Sari Pediatri, 8(1), 9-15. https://doi.org/10.14238/sp8.1.2006.9-15

Diana, W. (2019). Hubungan pola asuh orangtua dengan perkembangan motorik halus anak usia prasekolah di PAUD Harapan Bunda Surabaya. Journal of Health Educational Science and Technology)Nd Technology), 2(1), 51-60. https://doi.org/10.25139/htc.v2i1.1660

Dinkes Provinsi Bali. (2018). Profil kesehatan Provinsi Bali tahun 2017. Dinas Kesehatan Provinsi Bali.

Doni, A. W., \& Mukhtar, S. W. (2020). Hubungan pola asuh orang tua dengan pertumbuhan dan perkembangan anak prasekolah. Jurnal Kesehatan, 13(1), 46-52. https://doi.org/10.32763/juke.v13i1.180

Fatimah, L. (2012). Hubungan pola asuh orang tua dengan perkembangan anak di R.A Darussalam Desa Sumber Mulyo, Jogoroto, Jombang. Prosiding Seminas Competitive Advantage, 1(2), 1-6. http://www.journal.unipdu.ac.id/index.php/seminas/article/view/163

Hartanto, F., Selina, H., H, Z., \& Fitra, S. (2011). Pengaruh perkembangan bahasa terhadap perkembangan kognitif anak usia 1-3 tahun. Sari Pediatri, 12(6), 386-390. https://doi.org/10.14238/sp12.6.2011.386-90

Hasanah, U. (2016). Pola asuh orangtua dalam membentuk karakter anak. Elementary: Jurnal Ilmiah Pendidikan Dasar, 2(2), 72-82. https://ejournal.metrouniv.ac.id/index.php/elementary/article/view/pola-asuh-orangtua-dalammembentuk-karakter-anak

Kemenkes RI. (2013). Riset kesehatan dasar. Kementerian Kesehatan RI.

Lely, O., \& Soetjiningsih. (2010). Aspek kognitif dan psikososial pada anak dengan palsi serebral. Sari Pediatri, 2(2), 109-112. https://doi.org/10.14238/sp2.2.2000.109-12

Munir, Z., Yulisyowati, \& Virana, H. (2019). Hubungan pola asuh orang tua dalam menstimulasi perkembangan motorik kasar dan halus usia pra sekolah. Jurnal Keperawatan Profesional, 7(1), 1-17. https://ejournal.unuja.ac.id/index.php/jkp/index

Situmorang, T. S. K., Nurnaningsih, \& Sutomo, R. (2016). Perbedaan perilaku anak prasekolah berdasarkan pola pengasuhan. Sari Pediatri, 18(4), 314-319. https://doi.org/10.14238/sp18.4.2016.314-9

Supartini, Y. (2014). Buku ajar konsep dasar keperawatan anak. EGC.

Tridhonanto, A. (2014). Mengembangkan pola asuh demokratis. Elex Media Komputindo.

WHO. (2012). Global strategy for dengue prevention and control 2012-2020. World Health Organization. 